\title{
Nyugat és Kelet határán: Sopron a belföldi migrációban
}

\section{Sopron: a border town attracting internal migration}

\section{KISS ÉVA, JANKÓ FERENC, BERTALAN LAURA, MIKÓ ESZTER}

KISS Éva: tudományos tanácsadó, MTA Csillagászati és Földtudományi Kutatóközpont, Földrajztudományi Intézet; 1112 Budapest, Budaörsi út 45.; egyetemi tanár, Soproni Egyetem, Lámfalussy Sándor Közgazdaságtudományi Kar, Nemzetközi és Regionális Gazdaságtani Intézet; 9400 Sopron, Erzsébet u. 9.; kisse@helka.iif.hu; https://orcid.org/00000003-3605-9402

JANKó Ferenc: egyetemi adjunktus, Eötvös Loránd Tudományegyetem, Természettudományi Kar, Társadalom- és Gazdaságföldrajzi Tanszék; 1117 Budapest, Pázmány Péter sétány 1/C.; egyetemi docens, Soproni Egyetem, Lámfalussy Sándor Közgazdaságtudományi Kar, Nemzetközi és Regionális Gazdaságtani Intézet; 9400 Sopron, Erzsébet u. 9.; janko.ferenc@uni-sopron.hu; https://orcid.org/0000-0003-1149-6745

BERTALAN Laura: tanársegéd, Soproni Egyetem, Lámfalussy Sándor Közgazdaságtudományi Kar, Nemzetközi és Regionális Gazdaságtani Intézet; 9400 Sopron, Erzsébet u. 9.; bertalan.laura@uni-sopron.hu; https://orcid.org/0000-0002-1199-9257

MIKó Eszter: közgazdász; mikoeszter@gmail.com; https://orcid.org/0000-0002-8528-0739

KULCSSZAVAK: belföldi migráció; népesség; határváros; gazdasági válság; Sopron

ABSZTRAKT: A rendszerváltozás után a belföldi migrációban jelentős változások következtek be, amit több tényező (pl. gazdasági átalakulás, a szuburbanizáció felerősödése, a közlekedés fejlődése) indukált. Az egyes településeket különbözőképp érintette a belső vándorlás intenzívebbé válása, aminek demográfiai szempontból is vannak „nyertesei” és „vesztesei”. Az előbbiekhez sorolható az osztrák határ közelében fekvő, mintegy 63 ezer fós város, Sopron is, amely az egyik legnépszerübb célpont az országon belül vándorlók körében. Tanulmányunkban egyrészt Sopron szerepét értékeljük a belföldi migrációban, bemutatva azt, hogy a belső vándorlás különböző típusai hogyan járultak hozzá a város vándorlási nyereségéhez. Empirikus kutatásra alapozva arra keresünk választ, hogy kik a Sopronba bevándorlók, és hogy van-e lényeges különbség a bevándorlók jellemzőiben attól függően, hogy a legutóbbi gazdasági válság előtt vagy után érkeztek a városba.

Az elmúlt évtizedekben folyamatosan gyarapodott a népesség Sopronban, miközben az ország egészében és sok városában fogyott. A növekedés legfóbb forrása a vándorlási többlet volt, különösen az ezredforduló után. 1990 és 2016 között közel 13 ezer fős vándorlási nyereségre tett szert a város, elsődlegesen az ideiglenes bevándorlásból. A nagyarányú bevándorlás számos okra vezethető vissza (pl. a nyugati határ menti fekvés felértékelődése 1990 után, kedvezőbbé vált közlekedési kapcsolatok, relatíve közeli fekvés az osztrák fóvároshoz és Burgenland északi fejlettebb településeihez, az osztrák munkavállalási korlátozás feloldása). A felmérés tapasztalatai igazolták, hogy a gazdasági válság markáns fordulatot hozott az ezredforduló után Sopronba bevándorlók összetételében, munkapiaci ismérveiben és térkapcsolataiban. A 2009 után megfigyelhető új, kedvezőtlen trendek a helyi társadalomban is mélyreható változásokhoz vezethetnek.

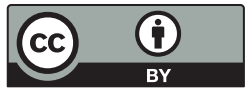


Éva KISS: scientific advisor, Geographical Institute, Research Centre for Astronomy and Earth Sciences, Hungarian Academy of Sciences; Budaörsi út 45., H-1112 Budapest, Hungary; professor, Institute for International and Regional Economics, Sándor Lámfalussy Faculty of Economics, University of Sopron; Erzsébet u. 9., H-9400 Sopron, Hungary; kisse@helka.iif.hu; https://orcid.org/0000-0003-3605-9402

Ferenc JANKÓ: assistant professor, Department of Social and Economic Geography, Faculty of Science, Eötvös Loránd University; Pázmány Péter sétány 1/C., H-1117 Budapest, Hungary; associate professor, Institute for International and Regional Economics, Sándor Lámfalussy Faculty of Economics, University of Sopron; Erzsébet u. 9., H-9400 Sopron, Hungary; janko.ferenc@uni-sopron.hu; https://orcid.org/0000-0003-1149-6745

Laura BERTALAN: assistant lecturer, Institute for International and Regional Economics, Sándor Lámfalussy Faculty of Economics, University of Sopron; Erzsébet u. 9., H-9400 Sopron, Hungary; bertalan.laura@uni-sopron.hu; https://orcid.org/0000-0002-1199-9257

Eszter MIKó: economist; mikoeszter@gmail.com; https://orcid.org/0000-0002-8528-0739

KEYWORDS: internal migration; population; border town; economic crisis; Sopron

ABSTRACT: After 1989, there have been changes in internal migration in Hungary, triggered by several factors such as economic transformation, accelerated suburbanisation and transport development. Increasing internal migration has affected each settlement differently, and from a demographic point of view there are also "winners" and "losers" in this process. Sopron, with almost 63,000 inhabitants, can be counted among the first group, as the town on the Austrian border is one of the most attractive destinations for Hungarian internal migration. In the past, the number of in-migrants usually exceeded the number of out-migrants. The differences depended largely on socio-economic transformations and the political situation of the respective period.

In this study, we assess Sopron's position in internal migration and analyse how the different types of internal migration have contributed to migration gains. Based on our empirical research, we show the main demographic and spatial-structural characteristics of the inmigrants to Sopron. In addition, we examine whether there are significant differences in the composition of migrants who arrived before and after the economic crisis of 2008, respectively.

In recent decades, the population of Sopron has grown steadily, while the populations in rural and other urban areas have declined. The main reason for the increase was the positive domestic migration balance which increased significantly after the turn of the millennium. Between 1990 and 2016, the population of the town rose by 13,000. This migration gain is primarily due to a temporary inflow. The most important reasons for the significant in-migration to Sopron were: a location-specific advantage after 1989 due to the nearby border, improved accessibility, relative proximity to the Austrian capital and the developed towns of neighbouring Burgenland and, finally, the abolition of all labour market restrictions in Austria in 2011.

The results of our survey reveal that the latest economic crisis has brought a significant change in the demographic composition of in-migrants after the turn of the millennium. The newcomers who arrived after 2009 were generally older, less-educated and found low-paying jobs in agriculture, industry and building construction. Their in-migration to Sopron was mainly motivated by job opportunities in Austria. The spatial pattern of their workplaces shows that they usually work in the region of the Austrian capital. Sopron's attraction extended almost over the whole country, and more and more in-migrants arrived from the less developed parts of Hungary. The new unfavourable trends observed in the social characteristics of in-migrants after 2009 may yet lead to changes in the local society and how it views their future integration. 


\section{Bevezetés}

A rendszerváltozás óta felerősödött az országon belüli népességmozgás, amelyben az egyes területek, illetve települések - számos tényezőtől függően - eltérő mértékben vesznek részt. A folyamatnak demográfiai szempontból is vannak nyertesei és vesztesei. Az előbbiekhez sorolható az osztrák határ közelében fekvő város, Sopron, mert népessége tetemesen gyarapodott az elmúlt évtizedekben, elsődlegesen a vándorlási többletnek köszönhetően. Ez nem újdonság, mivel a jelenleg kb. 63 ezer fös település földrajzi (Ausztriához közeli) fekvéséből adódóan nagy hagyományokkal rendelkezik a migráció terén (Hilbert 2016); a történelem során a városba bevándorlók általában (jóval) többen voltak, mint az elvándorlók. A vándorlási egyenleg alakulása nagymértékben függött az adott időszak társadalmi, gazdasági folyamataitól és az aktuális politikai helyzettől is, emiatt a város mint migrációs célpont „népszerüsége" szintén változott a különböző korokban.

Legutóbb a rendszerváltozás hozott markáns fordulatot nemcsak a város társadalmi, gazdasági fejlődésében, hanem földrajzi fekvésének megítélésében is (Jankó, Bertalan 2009). A szocializmus évtizedeiben az ország nyugati perifériáján, a vasfüggöny mentén, Kelet és Nyugat találkozásánál levő város földrajzi elhelyezkedése 1989 után felértékelődött (Hamilton 1995). Az új, kedvezőbb földrajzi-geopolitikai helyzet más tényezőkkel párosulva (pl. a közlekedési kapcsolatok javulása Ausztria irányába, az országhatár átjárhatóságának fokozódása) hozzájárult ahhoz, hogy Sopron vonzása egyre határozottabban érvényesüljön az ország más területei felé. Így a város egyike lett a belföldi migráció szempontjából Magyarország legvonzóbb településeinek, ami demográfiai konzekvenciákkal is jár (Kiss 2016). Tanulmányunkban egyfelől a város országon belüli migrációban játszott szerepét értékeljük, másfelől arra keresünk választ - egy empirikus kutatásra alapozva -, hogy kik azok, akik hosszabb-rövidebb időre beköltöztek. Továbbá kíváncsiak vagyunk arra, hogy a beköltözők milyen térkapcsolatokkal rendelkeznek, honnan, mikor és miért jöttek Sopronba és hova tartanak, mik a szándékaik. Azt is megvizsgáljuk, hogy mennyiben különböznek az előbb említett szempontok szerint a gazdasági válság után bevándorlók az azt megelőzően érkezőktől.

Először a kutatás elméleti hátterével, a belföldi migrációkutatás néhány sajátosságával foglalkozunk, majd a statisztikai adatokra alapozva értékeljük Sopron belföldi migrációban betöltött szerepét. Ezután egy 2017 elején végzett kérdőíves felmérés tapasztalatait foglaljuk össze, amely a városba bevándorlókról nyújt ismereteket. A soproni eredmények azért is figyelmet érdemlők, mert a város - bizonyos fokig - egyedülálló helyet foglal el a belföldi migrációban, és mert támpontokat adhatnak más, nyugati határ menti települések migrációs szerepkörének megítéléséhez, valamint azért, mert újabb adalékokat szolgáltatnak az országon belüli migrációban részt vevőkről. 


\section{Tudományos előzmények}

A kutatás során a rendkívül gazdag nemzetközi és hazai migrációs szakirodalomból elsődlegesen azokra támaszkodtunk, amelyek az országon belüli közigazgatási határ (pl. településhatár) átlépésével járó migrációról szólnak. Annak ugyanis, hogy hol és milyen irányba vándorol a népesség egy országon belül, komoly társadalmi és gazdasági hatásai lehetnek, amelyek az élet minden területét érinthetik (Flowerdew 2004). A fejlett országokban végzett kutatások kimutatták például, hogy egy belga tartományban azok a települések léptek be a legnagyobb egy före jutó jövedelmü települések csoportjába, amelyek magas jövedelmű migránsokat tudtak vonzani (Peeters 2008). Spanyolországban bebizonyították, hogy a belső migráció befolyásolja a vízfogyasztás területi különbségeit (March, Perarnau, Sauri 2012). Az sem vitatható, hogy a gazdaságban bekövetkező változások visszahatnak a migrációra. Japánban például a gazdasági válság miatt mérséklődött a mobilitás az ország három (Tokió, Oszaka, Nagoja) nagyvárosi térségében 2008 és 2010 között (Ishikawa 2011). De a migráció intenzitása és iránya más okok miatt is megváltozhat. A belföldi migráció okainak vizsgálata az egyik leggyakoribb téma, amelyet sokféle aspektusból kutattak a különböző országokban, többnyire hasonló eredményekkel. Az Egyesült Királyságban arra a következtetésre jutottak, hogy az életciklus és a társadalmi, gazdasági tényezők a legfontosabbak a lakhatási célú migrációs folyamatokban (Clark, Huang 2004). Németországban a belső vándorlást, különösen Kelet- és Nyugat-Németország között, kezdetben politikai és gazdasági okok motiválták, később a társadalmi kapcsolatok és a lakásszerzés (Kemper 2004). Svédországban az újabb becslések is megerősítették, hogy a bérek és a munkanélküliség releváns tényezők a migrációs döntésekben (Gärtner 2016).

A rendszerváltozás után a posztszocialista országokban is fellendült a belső migráció kutatása, amit - többek között - a regionális különbségek fokozódása, a gazdaság radikális átalakulása, a szuburbanizáció intenzívebbé válása és a földrajzi fekvés felértékelődése befolyásolt. Bizonyságot nyert, hogy az itteni tapasztalatok bár sok hasonlóságot mutatnak a fejlett országokban megfigyeltekhez, mégis vannak sajátos vonások, amelyek alapvetően a múlt örökségéből fakadnak (Kulu, Billari 2004). Az éles regionális különbségek szintén ezek közé sorolhatók, amelyek tovább éleződtek az elmúlt évtizedekben, jóval aránytalanabb népességmegoszlást eredményezve (Kurkó 2011; Mainardi 2004; Mikačić 2000).

Hazánkban szintén több elemzés készült a belső migráció területi, településhálózati ismérveiről, amelyek nemcsak a migráció időbeli alakulását, hanem a migrációban részt vevők demográfiai vonásait, motivációit, a migráció fő küldő és fogadó területeit is feltárták (Bálint, Daróczi 2014; Dövényi 2007, 2009; Ginter 2008; Illés 1995; Kapitány 1998). Közismert, hogy a magyar népesség migrációs hajlandósága igen alacsony, és hogy a belső migráció viszonylag rövid múltra tekint vissza (Dövényi 2007). A szocializmus első évtizedeiben a nagy 
távolságú vagy interregionális migráció dominált, a jelentős gazdasági változásokkal összefüggésben. Az 1970-es évektől a rövid távolságú (intraregionális), többnyire megyén belüli népességmozgások kerültek előtérbe. A rendszerváltozással viszont új korszak kezdődött a belföldi migrációban (Dövényi 2007; Ginter 2008). Ennek hátterében elsősorban az állt, hogy a városokhoz közeli lakóhelyi környezet felértékelődött, a gazdaság, leginkább az ipar térszerkezete átalakult, az egyes helyek elérhetősége és a közlekedési kapcsolatok sokat javultak, valamint a földrajzi helyek „értéke” is megváltozott. Következésképp jó néhány olyan (pl. nyugati határ menti) település vált vonzó célponttá, amely korábban nem volt az (Lukić et al. 2014). Ez lényegében annak az eredője, hogy a határ két oldalán tetemes különbségek vannak pl. a bérekben, a munkakörülményekben, a gazdasági fejlettségben, az életszínvonalban. A bevándorlás következtében ezekben a településekben igen látványosak a migráció hatásai (Dittrich-Wesbuer, Föbker, Osterhage 2008; Kumpulainen 1994; Lukić et al. 2014; West, Gans, Schmitz-Veltin 2008).

A külföldi migrációs szakirodalomban kevés, a hazaiban pedig szinte nem is akad olyan publikáció az utóbbi évtizedekből, amely egy-egy település belföldi migrációban játszott szerepét értékelné vagy annak az adott település társadalmára, gazdaságára gyakorolt hatásait tárná fel. Éppen ezért fontos és bizonyos fokig hiánypótló a soproni kutatási eredményeket összefoglaló írásunk.

\section{Sopron a belföldi migrációban 1989 után}

A rendszerváltozás több szempontból is fordulatot hozott Sopron népesedésében. Egyrészt megszűnt a természetes szaporodás, mert a halálozások száma mind jobban meghaladta a csökkenő számú születésekét. Másrészt ismét növekedésnek indult a vándorlási különbözet értéke, ami a belföldi vándorlás három típusának (állandó, ideiglenes, visszavándorlás) az együtteséből fakad és egyre nagyobb szerepet játszik a természetes fogyás ellensúlyozásában. Az 1990-es években a vándorlási többlet elmaradt a 21. század első évtizedében elért értéktől, ezért akkor kisebb mértékben nőtt a népesség. A legutóbbi népszámlálás óta tovább folytatódott a bevándorlás, s továbbra is tetemes a vándorlási nyereség (1. táblázat).

A város népességnövekedését azért szükséges hangsúlyozni, mert az ország egészében és nagyon sok településében folyamatosan apadt a népesség az elmúlt évtizedekben. 1990 és 2016 között közel 13 ezer fös vándorlási nyereségre tett szert Sopron; 1990 és 2006 között az 50-100 ezer lakosú városok közül egyedül itt volt vándorlási többlet (Ginter 2008), 2007 és 2016 között pedig a legnagyobb vándorlási többletre tett szert a város, Budapestet nem számítva. Az a tény viszont, hogy más, nyugati határ menti városban (pl. Kőszeg, Szentgotthárd) a vándorlási nyereség szerényebb volt (ami nem csak ezen városok 
1. táblázat: Sopron népmozgalma, 1980-2016 (fo) Vital statistics of Sopron, 1980-2016 (persons)

\begin{tabular}{cccccc}
\hline Idöszak & Élveszületés & Halálozás & $\begin{array}{c}\text { Természetes } \\
\text { szaporodás, } \\
\text { illetve fogyás }\end{array}$ & $\begin{array}{c}\text { Vándorlási } \\
\text { különbözet }\end{array}$ & $\begin{array}{c}\text { Tényleges } \\
\text { szaporodás, } \\
\text { illetvefogyás }\end{array}$ \\
\hline $1980-1990$ & 6279 & 6088 & 191 & 56 & 247 \\
$1991-2000$ & 5831 & 6893 & -1062 & 2154 & 1092 \\
$2001-2011$ & 5709 & 6975 & -1266 & 5639 & 4373 \\
$2012-2016$ & 2677 & 3363 & -686 & 2802 & 2116 \\
\hline
\end{tabular}

Adatok forrása: népszámlálások megyei kötetei; Györ-Moson-Sopron megye Statisztikai Évkönyve; demográfiai évkönyvek.

kisebb méretére vezethető vissza) azt sejteti, hogy Sopronnak sajátos vonzó tényezője van. Feltételezhető, hogy ez a „különleges adottság” abból a sajátos földrajzi elhelyezkedéséből fakad, hogy közelebb van Bécshez és Burgenland északi, fejlettebb területeihez, mint a többi nyugati határ menti város (1. ábra).

Sopron vándorlási egyenlegének alakulásában semmilyen általános irány nem figyelhető meg, ezért a magyar közép- és nagyvárosok 1979 és 2002 közötti migrációs trendjei alapján kialakított öt migrációs típus közül a „hektikus” cso-

1. ábra: A megyei jogú városok és néhány nyugati határ menti város vándorlási különbözete, 2007-2016

Internal migration balance of major Hungarian towns and some Western border towns, 2007-2016

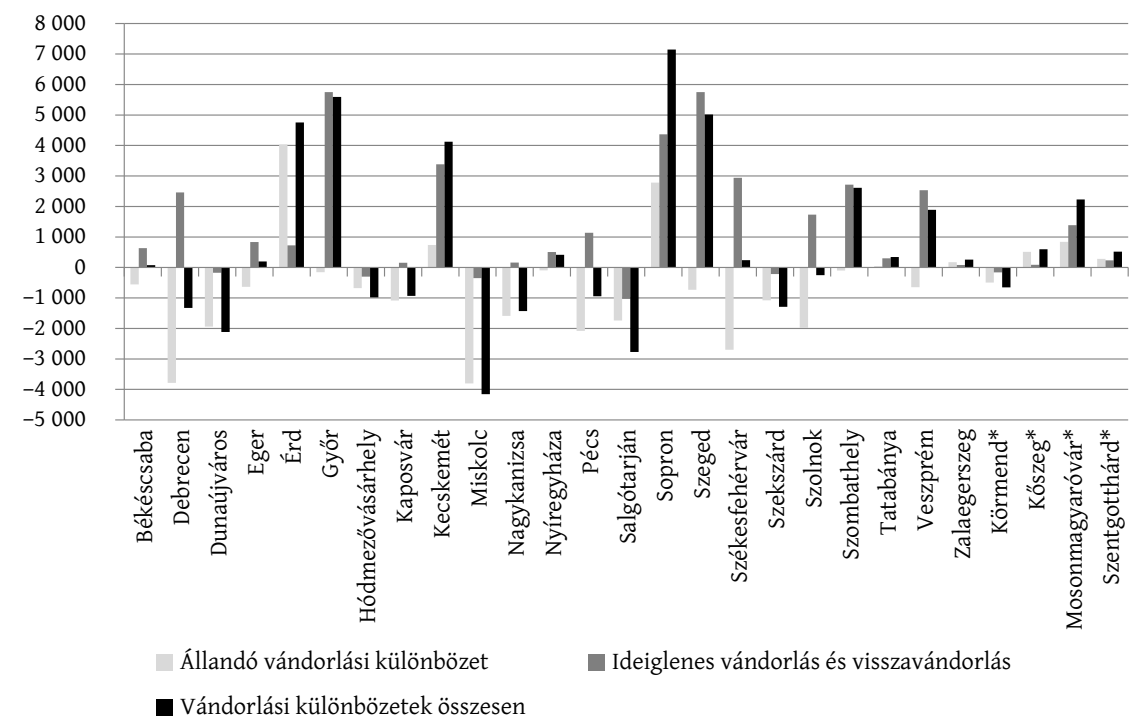

Megjegyzés: Budapestet kiugró értékei (állandó vándorlási különbözet: 9787 fó, ideiglenes és visszavándorlás különbözete: 63281 fó, összesen: 73068 fó) miatt nem ábrázoltuk.

Adatok forrása: demográfiai évkönyvek, 2007-2016. 
portba tartozik (Zábrádi 2005). A hektikusság, amely 2002 után is nyomon követhetö, alapjában véve a pozitív tartományon belül valósul meg (2. ábra). Mindössze egyetlen esztendőben, 1999-ben volt negatív a vándorlási különbözet értéke (-6 fö). A bevándorlás a leginkább a gazdasági válság után erősödött fel: amíg 1990 és 2008 között általában 500 fö alatt volt a vándorlási különbözet értéke, addig 2009-től már 800-1000 főre szökött fel. A vándorlási különbözetek görbéinek futásában kijelölhetők azok a „fordulópontok” (pl. a 2001-es egyesült államokbeli terrortámadás, az EU-csatlakozás, az ausztriai munkaerőpiaci kvóták eltörlése 2011-ben), amelyek pozitív vagy negatív irányba befolyásolták a migráció intenzitását. Szintén nagyon csekély vándorlási veszteség (-17 fö) következett be 2015-ben, ami a korábbiakhoz képest jóval nagyobb visszavándorlásnak tulajdonítható (többen, akiknek tartózkodási helye volt a város, visszaköltöztek a lakóhelyükre).

A migrációs szakirodalomban jól ismert az a megállapítás, hogy a nagy történelmi fordulatokra növekvő térbeli mobilitással reagál a népesség (Dövényi 2007). Tulajdonképpen ezt várták a szakemberek 1989 után is, a valóság ellenben az volt, hogy csökkent az országon belüli mobilitás (Illés 1995; Dövényi 2007). Sopronban is szinte alig gyarapodott a népesség az állandó vándorlási többletnek köszönhetően az 1990-es évek első felében. Azt követően viszont egyre inkább a város vonzó hatása kerekedett felül, habár az elvándorlások száma is emelkedett. Majd az ezredfordulótól magas szinten stabilizálódott az állandó bevándorlók (1100-1200 fó/év) és az állandó elvándorlók (800-900 fó/év) száma; az éves állandó vándorlási nyereség 300-400fó volt. A tartós helyváltoz-

2. ábra: A vándorlási különbözet Sopronban és főbb befolyásoló tényezői, 1990-2016 Internal migration balance in Sopron and their major influencing factors, 1990-2016

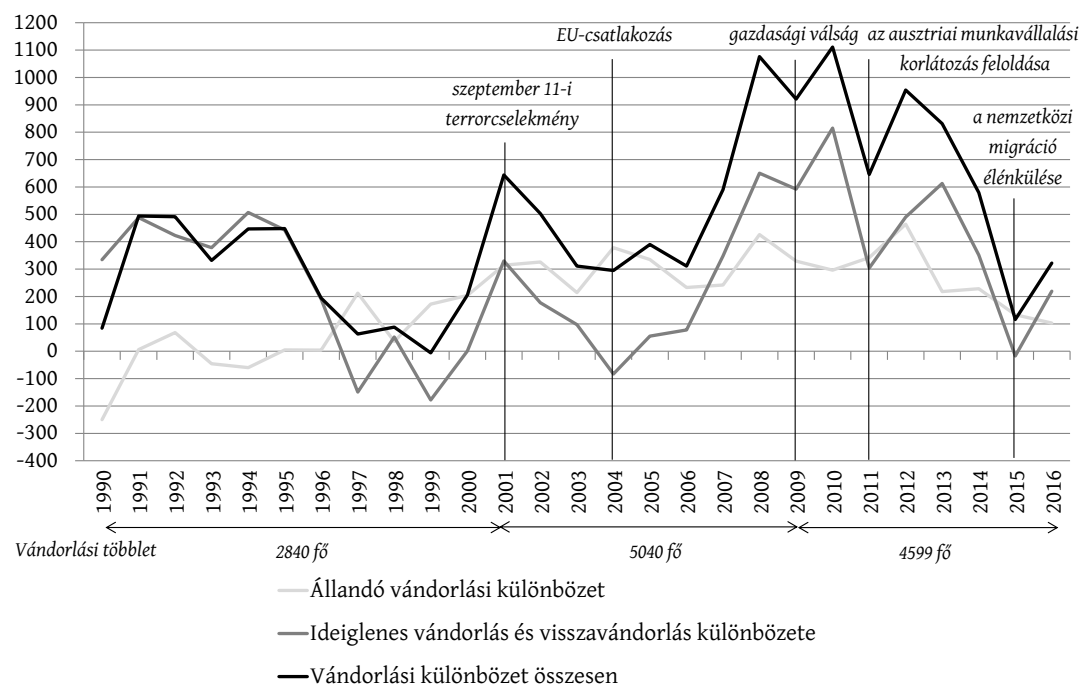

Adatok forrása: demográfiai évkönyvek. 
tatásra törekvő népesség mobilitása fokozódott. Az ország egészében az 1990-es években felgyorsult szuburbanizáció Sopronban csak kis mértéket öltött, ami leginkább annak következménye, hogy a város belterületi határát kijjebb tolták, és hogy a közigazgatásilag hozzá tartozó településekre (Balf, Brennbergbánya, Sopronkőhida, Tómalom) irányult a népességmozgás (Jankó 2004). A város közigazgatási határán belülre koncentrálódott „látens” szuburbanizációt csak később váltotta fel a valódi szuburbanizáció.

Az állandó vándorlást mozgató okok között - az országos tapasztalatokat alapul véve - csökken a munka szerepe, amelyet egyre inkább kivált az ingázás (Kapitány 1998). Ez összhangban van azzal a felismeréssel, hogy a munkahelyváltás nem szükségszerüen követeli meg a lakhelyváltozást (Green 2004). Az a széles körben elterjedt vélekedés is egyre kevésbé tartható, hogy a munkavégzési célú migráció általában nagyobb távolságra történik, mint a lakhatás miatti (Clark, Huang 2004; Niedomysl 2011); bár kétségtelen, hogy a munkahelyváltás a nagy távolságra történő lakóhelyváltás elsődleges motivációja (Clark, Huang 2004). Idehaza szintén mérséklődik a lakhatás és a család miatti vándorlás, miközben növekszik az egyéb okok (pl. a település minősége, a fejlettebb ország közelsége) magyarázó ereje (Illés 1995, 1998).

A Sopronba ideiglenesen bevándorlók éves száma általában 1100-1200 fó között volt 1990 és 2006 között, míg az ideiglenes elvándorlóké 400-500 fő között. 2007-től azonban tartósan megemelkedett az ideiglenes bevándorlók száma 500-1000 fóvel, miközben az ideiglenes elvándorlóké csak 100-200 fővel lett több 2007-2016 között. A nagyarányú ideiglenes bevándorlásnak kezdetben az lehetett az oka, hogy a gazdasági válság folytán nőtt a munkanélküliség és beszükültek a hazai munkalehetőségek; 2011 után viszont valószínüleg az osztrák munkaerőpiac megnyitása. Egyre többen próbáltak szerencsét Sopronban, mert úgy vélték, hogy onnan könnyebben tudnak majd a szomszédos Ausztriában munkához jutni. Annak, hogy nem az állandó vándorlók számát gyarapították, több magyarázata lehet. Az egyik ok, hogy mivel többen az ország távolabbi részeiből érkeznek, a csekély helyismeret miatt először csak „felmérték” a lehetőségeket. Ha nem jött be a számításuk, akkor viszonylag könnyen vissza tudtak menni oda, ahonnan jöttek. (Ez magyarázhatja a megnövekedett ideiglenes elvándorlást.) A másik ok, hogy sokuk csak ,átmeneti” megoldásnak tekinti a Sopronba vándorlást. Nem szándékoznak végleg áttelepülni, mert a családi, rokoni, baráti és egyéb kapcsolatok a távoli, állandó lakóhelyhez kötik őket. A harmadik ok, amely részben az előbbivel is összefügg, hogy a „végleges” Sopronba települést a soproni magas ingatlanárak és a szükös ingatlankínálat miatt nehéz megvalósítani. Szintén fontos megjegyezni, hogy a Sopronba ideiglenesen bevándorlók egy részét a helyi egyetemen tanulók teszik ki, akiknek tekintélyes hányada tanulmányai befejezése után minden bizonnyal máshol telepedik majd le.

A Sopronba visszavándorlók száma többnyire 300-400 fót tesz ki évente, tehát a várost elhagyók csak kismértékben térnek vissza. A visszavándorlás 
okairól csak feltételezésekre támaszkodhatunk. A legvalószínűbb az, hogy családi (pl. nyugdíjba vonulás) és lakhatási természetű okai vannak (pl. öröklés folytán a megüresedett szülői házba való visszaköltözés), semmint tanulással (pl. a tanulmányok befejezése) vagy munkával összefüggők.

A Sopronba évente bevándorlók száma az 1990-es években elérte az 19002500-at, a legutóbbi gazdasági válság után azonban már a háromezret is meghaladta. Ezzel szemben a városból elvándorlók jóval kevesebben voltak, ezért Sopron népessége évente több száz fővel gyarapodott a rendszerváltozás óta. De kik azok, akik a városba bevándoroltak hosszabb-rövidebb időre?

\section{A Sopronba bevándorlók az empirikus kutatás alapján}

\section{A felmérés módszere és a válaszolók fóbb jellemzői}

A soproni népesség, illetve a bevándorlók alaposabb megismerése érdekében online kérdőíves felmérést végeztünk 2017 elején, felhasználva a hólabdamódszert és a közösségi média felületeit. Bár ez a módszer viszonylag gyors és olcsó, nyilvánvalóak a korlátai is. Például a minta nem reprezentatív, az internethasználat nem általános volta eleve leszúkíti a potenciális válaszadók körét. Ennek ellenére meggyőződésünk, hogy a felmérés eredményei alkalmasak arra, hogy információkat szolgáltassanak a városba beköltözőkről. A kérdőív 15 kérdést tartalmazott, amelyek a válaszadók demográfiai, foglalkozási ismérveire, térbeli mobilitásuk részleteire, valamint jövőbeni mobilitási szándékaikra vonatkoztak.

A kérdőívet 782-en töltötték ki, ez a város népességének mintegy 1,3\%-át teszi ki. A válaszadók között 460 nő és 322 férfi volt, ami nem véletlen, hiszen a nők nagyobb valószínűséggel válaszolnak a kérdőívekre. A korstruktúra 16 és 82 év között mozgott, de a legtöbben a 35-55 éves korcsoportba tartoztak. A többség magasan kvalifikált volt, $25 \%$-uk föiskolai és $20 \%$-uk egyetemi végzettséggel. A válaszadók töredéke (9\%) dolgozott a tercier szektoron kívül, azaz a mezőgazdaságban vagy az iparban. A kékgallérosok aránya 8\%-ot tett ki, míg az Ausztriában munkát vállalóké 19\%-ot. Akadtak olyanok is (8\%), akik felváltva dolgoztak Ausztriában és Magyarországon.

A válaszolókat két fö csoportba osztottuk: a régi és az új lakosok körére. Előbbiek (563 fö) közé azok tartoznak, akik születésüktől fogva a városban laknak vagy az ezredforduló előtt költöztek oda. A 2000 után beköltözők (219fö), a válaszadók 28\%-a új lakos, akik két alcsoportra bonthatók, attól függően, hogy a legutóbbi válság előtt vagy azután érkeztek a városba: az új lakosokból 79 érkezett 2009 előtt és 140 fó azután. A továbbiakban a hangsúlyt az ezredforduló után bevándoroltak bemutatására helyezzük. 


\section{A kérdoives felmérés fontosabb eredményei}

A régi lakosokhoz viszonyítva az újak fiatalabbak, 78\%-uk 35 év alatti volt, ami nem csoda, hiszen általában a fiatalok vesznek részt nagyobb arányban a migrációban (Dövényi 2009; Sik, Szeitl 2016). A legutóbbi válság után megugrott a 25-34 éves korcsoportba tartozók aránya a bevándorlók között, tehát a gazdasági krízis következtében sok fiatal döntött a Sopronba költözés mellett. A 2000-2009 között érkezettek táborában kevesebb volt a házas és részben ezáltal a gyermekesek aránya is. Ebből arra lehet következtetni, hogy a gazdasági válság folytán olyan mértékben romlott meg bizonyos családok pénzügyi-gazdasági helyzete, hogy több gyerekes család kelt útra. A gyerekkel érkezők aránya 15\%-ról 23\%-ra nőtt, míg a párkapcsolattal rendelkezőké 25\%-ról 41\%-ra. A fiatal (gyerekes) párok együttes migrációját minden bizonnyal az motiválta, hogy így nagyobb biztonságban érezhetik magukat egy új, számukra idegen településen és könnyebben kerekednek felül a nehézségeken, mert számíthatnak egymásra. Szintén magasabb lett az 55 év felettiek aránya (3,5\%) az utóbbi időben, amit a leginkább a családhoz, a gyermekekhez, a szülőkhöz való közelebb kerülés motivált (2. táblázat).

Az ezredforduló után beköltözők között az iskolai végzettségben és a foglalkozási szerkezetben is különbségek fedezhetők fel. A 2009 után érkezettek körében kevesebb a diplomás (45\%), több az általános iskolát végzett (3\%) és viszonylag magas a szakmunkásképzőt végzettek aránya (33\%). Az alacsonyabb iskolai végzettség nagyobb gyakoriságával is magyarázható, hogy több a kevésbé kvalifikált munkaerőt igénylő munkakörökben dolgozó, a segéd- és a betanított munkás az utóbbi évtizedben bevándoroltak között és kevesebb a vezető beosztású, illetve az értelmiségi foglalkozású. A mezőgazdaságban (3\%), az iparban (13\%), az építőiparban (8\%) és a kereskedelemben (21\%) munkát vállalók magas(abb) hányada szintén erre vezethető vissza, csakúgy mint a tartós munkanélküliek nagyobb aránya (3\%). Ezzel szemben a gazdasági válság előtt bevándoroltak nagyjából 10-10\%-a dolgozott az iparban, a kereskedelemben, a közlekedés, szállítmányozás terén és a vendéglátásban. A válság előtt és után érkezett új lakosok foglalkozásának ágazati megoszlását összevetve a legnagyobb növekedés az agrárszektorban, az építőiparban és a kereskedelemben következett be. Ezek az ágazatok pedig többnyire nem magasan kvalifikált munkaerőt foglalkoztatnak (3. ábra).

2. táblázat: A soproni új lakosok kormegoszlása (\%)

Newcomers to Sopron by age groups (\%)

\begin{tabular}{lrrrrrr}
\hline \multicolumn{1}{c}{ Megnevezés } & -24 & $25-34$ & $35-44$ & $45-54$ & $55-64$ & $65-$ \\
\hline 2000-2009 között beköltözöttek & 57,0 & 26,6 & 11,4 & 5,1 & 0,0 & 0,0 \\
2010-2017 között beköltözöttek & 36,4 & 38,6 & 13,6 & 7,9 & 2,1 & 1,4 \\
\hline Beköltözők összesen & 43,8 & 34,2 & 12,8 & 6,9 & 1,4 & 0,9 \\
\hline
\end{tabular}

Adatok forrása: kérdőives felmérés, 2017. 
3. ábra: A soproni új lakosok iskolai végzettség (fent) és munkaerőpiaci helyzet (lent) szerint Newcomers to Sopron by education (above) and labour market (below) position

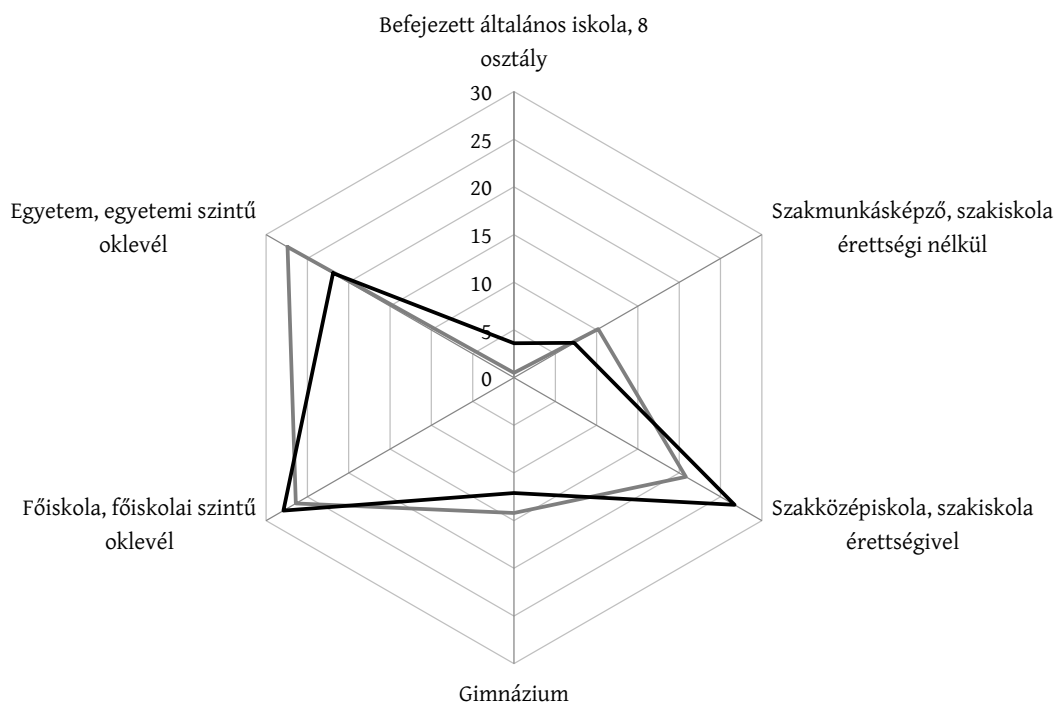

—2000-2009 között költözött a városba — —2009 után költözött a városba

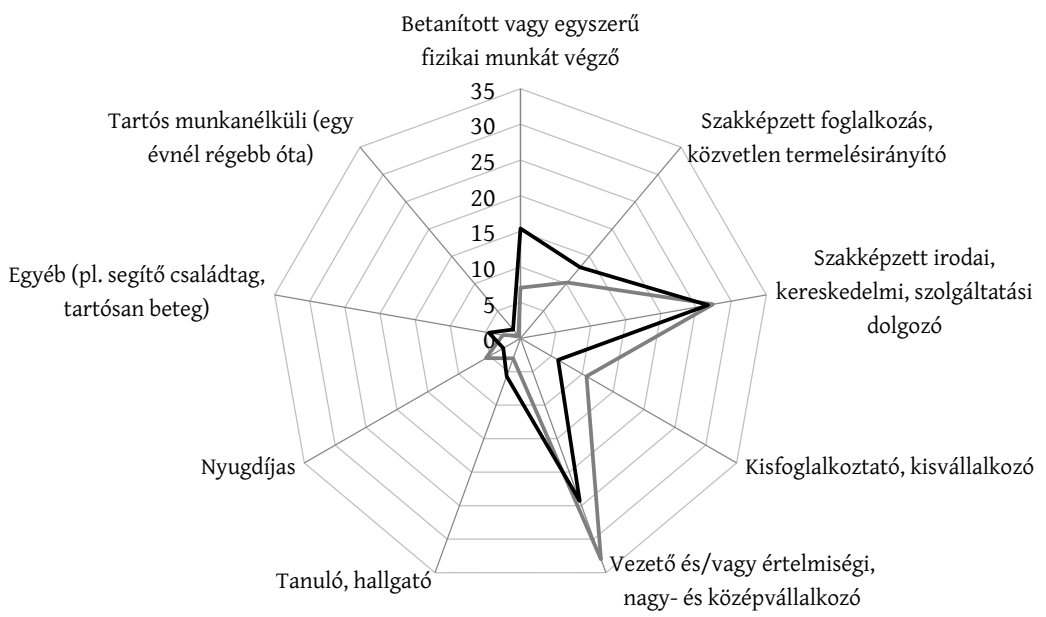

—2000-2009 között költözött a városba — —2009 után költözött a városba

Adatok forrása: kérdőives felmérés, 2017. 
A migrációt rendszerint több tényező együttese váltja ki, amelyek a leggyakrabban néhány fő ok (pl. munka, család, tanulás) köré csoportosulnak. Az új bevándorlók 48\%-a elsősorban azért ment Sopronba, hogy valamilyen munkát találjon a városban, a város környékén vagy Ausztriában. Ezt feltételezhetően az motiválta, hogy a válság következtében a munkalehetőségek csökkentek a lakóhelyükön, hiszen az ország kevésbé fejlett részeiben tartósabbak voltak a legutóbbi gazdasági válság hatásai (Kiss 2011). A gazdasági válságot követően az ausztriai munkalehetőség óriási vonzást fejt ki a bevándorlókra, akiknek egy része naponta ingázik Sopronból, mert a szállás, a megélhetés olcsóbb Sopronban, mint Ausztriában. Ez a megosztottság, hogy a lakás Sopronban és a munka Ausztriában van, jó lehetőséget biztosít az érintett családok jövőjének megalapozásához. Mindezek tükrében a városnak, amely híd, összekötő kapocs a munkahely és a lakóhely között, akár sorsfordító szerepe is lehet.

A felmérés szerint a 2009 után Sopronba irányuló migráció hajtóerői között a munka jelentősége erősödött; a város a munkavállalás miatti belföldi migráció egyik kiemelkedő célpontja lett. A családi és egyéb személyes kapcsolatok miatti vándorlás mérsékeltebben nőtt, ugyanakkor a tanulás miatti bevándorlás drasztikusan visszaesett. Ez a város oktatási szerepkörének és felsőoktatási intézménye vonzásának módosulásával függhet össze, de elképzelhető, hogy a potenciális egyetemi hallgatók számának országos csökkenése is közrejátszik benne. A gazdasági válság előtt a bevándorlók kb. egyharmada tanulni jött Sopronba, a válság után azonban felére csökkent az arányuk. Az egyéb bevándorlási okokhoz soroltuk többek között a város szépségét, kedvező földrajzi fekvését, jó levegőjét, sajátos hangulatát vagy megnyerő külsejét (3. táblázat).

Sopronban régóta nagy hagyományai vannak az osztrák munkavállalásnak (Kincses 2012). A motiváló tényezőkkel összhangban 2009 után jóval több új lakos vállalt Ausztriában munkát, ellenben a Sopronban és környékén munkát vállalók száma csökkent, de a legtöbben még mindig a városban és térségében dolgoznak. Amíg a 2009 előtt bevándoroltak 12\%-a jár Ausztriába dolgozni, addig a később beköltözők 31\%-a. Úgy is fogalmazhatunk, hogy a válság előtt inkább a soproni, azután viszont az osztrák munkavállalás lehetősége jelentette a város fő vonzerejét.

3. táblázat: A soproni új lakosok a beköltözés oka szerint (\%) Newcomers to Sopron by causes of immigration (\%)

\begin{tabular}{|c|c|c|c|c|c|}
\hline \multirow[t]{2}{*}{ Megnevezés } & \multicolumn{2}{|c|}{ Munka } & \multirow[t]{2}{*}{ Tanulás } & \multirow{2}{*}{$\begin{array}{c}\text { Személyes (barát, } \\
\text { család, rokon stb.) } \\
\text { kapcsolatok }\end{array}$} & \multirow[t]{2}{*}{ Egyéb } \\
\hline & Sopronban & Ausztriában & & & \\
\hline 2000-2009 között beköltözöttek & 29,2 & 9,0 & 30,4 & 29,2 & 2,2 \\
\hline 2010-2017 között beköltözöttek & 26,4 & 23,0 & 14,4 & 31,0 & 5,2 \\
\hline Beköltözők összesen & 27,4 & 18,2 & 19,8 & 30,4 & 4,2 \\
\hline
\end{tabular}

Adatok forrása: kérdöíves felmérés, 2017. 
Lényegében nem változott az osztrák munkavállalás célterülete. A válaszok alapján megállapítható, hogy a 2009 után érkezettek ausztriai munkavállalásának helyszínei térben koncentráltabbak, mint a korábban bevándoroltaké. Az elsődleges célpont Bécs. Ennek hátterében az állhat, hogy Burgenlandban és a Sopronhoz közeli területeken már nem volt sok munkalehetöség (azokat elfoglalták a korábban beköltözők vagy a régi lakosok), továbbá hogy a bérek alacsonyabbak ott, mint az osztrák fővárosban. Bécs mellett Wiener Neustadt és Burgenland északi, fejlettebb fele (Eisenstadt és környéke) a legvonzóbb, amihez az is nagyban hozzájárult, hogy a közlekedési kapcsolatok sokat javultak a rendszerváltozás óta, az országhatáron való átkelés jóval egyszerűbb lett, például új határátkelőhelyek nyíltak (4. ábra).

4. ábra: A soproni új lakosok az ausztriai munkahelyük szerint Newcomers to Sopron by the location of their workplace in Austria

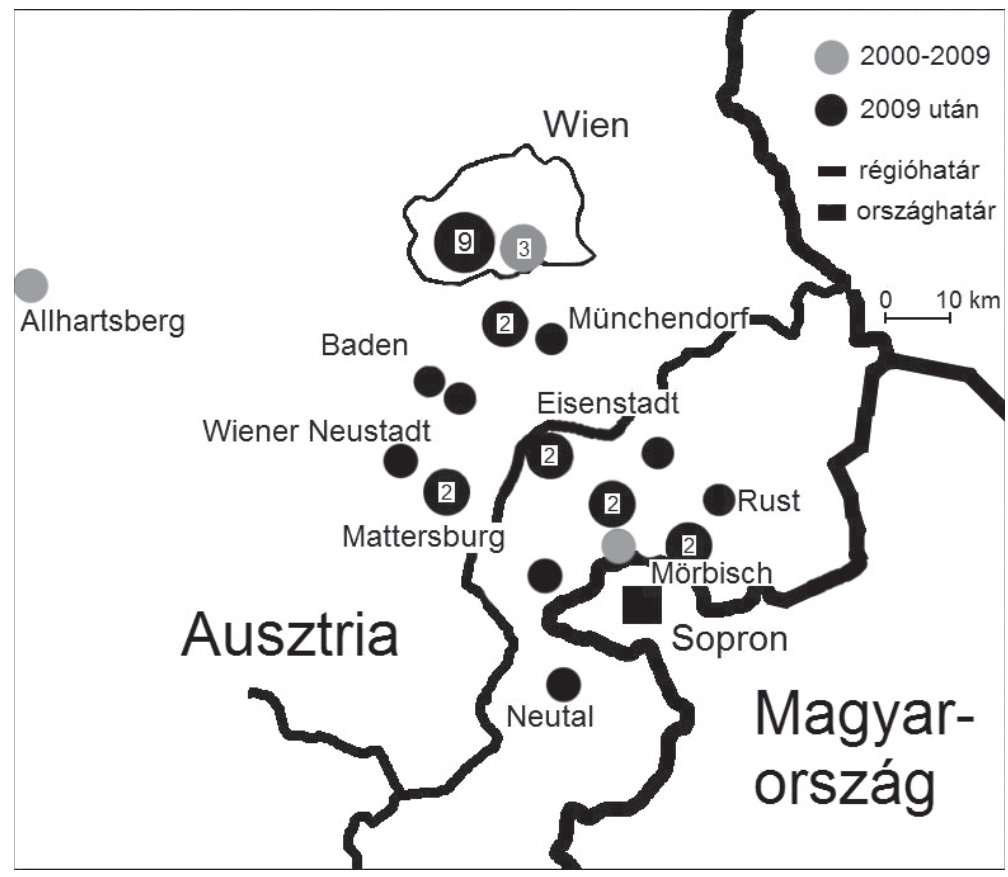

Adatok forrása: kérdőives felmérés, 2017.

Az elmúlt évtizedekben nemcsak a bevándorlók száma ugrott meg, hanem a város munkahelyi vonzásterülete is kiszélesedett. Bár tradicionálisan még mindig a Nyugat-dunántúli régióból érkeznek a legtöbben Sopronba, de arányuk csökken. Ezzel párhuzamosan növekszik az ország más térségeiből bevándorlóké. Sopron vonzása nemcsak az elmaradottabb, jobbára északkeleti országrészekre terjed ki, hanem a fejlettebb, távolabbi országrészekre is (pl. Közép-magyarországi régió). A legtöbben a Zalaegerszeg-Nyíregyháza-vonaltól 


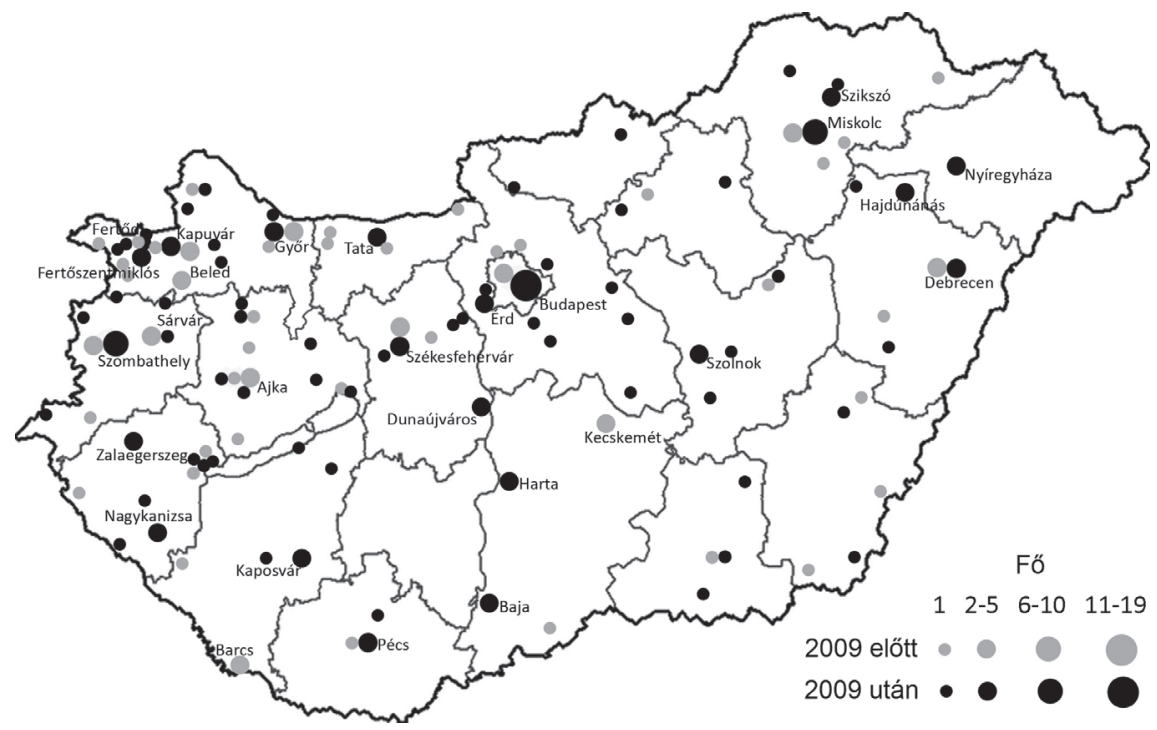

Adatok forrása: kérdőives felmérés, 2017.

északra levő országrészből származnak; a város kevésbé vonzó az ország déli felében (pl. Dél-Alföld, Dél-Dunántúl) lakók számára. A gazdasági válság előtt 48 településről költöztek be Sopronba, míg utána 76-ból, ami a települési kör bővülését jelzi (5. ábra).

Az új lakosok rendszerint hosszú távra terveznek, még ha a 2009 után érkezettek körében ez a szándék némiképp mérséklődött is (82\%-ról 66\%-ra). Szintén ezt támasztja alá, hogy majdnem megháromszorozódott az öt évnél rövidebb időre Sopronba bevándorlók aránya, arányuk 6,4\%-ról 18,6\%-ra szökött fel az utóbbi évtizedben. Növekedett azoknak is az aránya, akik tovább szeretnének majd költözni a városból vagy Ausztriába, vagy az országon belül más településre. Ennek ellenére a legtöbb új lakos (51\%) még mindig a „hűség városát” választja új lakóhelyének hosszú távra. A letelepedés nemcsak új lehetőség, hanem jelentős változások kiváltója is lehet a város társadalmában és gazdaságában.

\section{Összefoglalás}

Sopron több szempontból is egyedülálló helyet foglal el az országon belüli migrációban. A rendszerváltozás óta az egyik legvonzóbb település, népessége töretlenül gyarapodott, amit kevés más hazai település mondhat el magáról. 
Ebben egyre nagyobb szerepe volt a pozitív vándorlási egyenlegnek, amely felülmúlta a természetes fogyás értékét. Főleg a gazdasági válság utáni időszakban nőtt meg a bevándorlók száma, kiváltképp az ideiglenesen bevándorlóké. Az empirikus kutatás tapasztalatai megerősítették azt a hipotézist, hogy a gazdasági válság fordulatot hozott a Sopronba irányuló migrációban. A 2009 után bevándorlók demográfiai, munkaerőpiaci, térkapcsolati jellemzői különböznek a válság előtt érkezőkétől. Új, kedvezőtlen jelenségek figyelhetők meg a határ menti város népességében, amelyek a kutatás folytatásának további irányait is kijelölik. Az egyik, hogy a nagyarányú bevándorlás hogyan hatott a helyi lakosság összetételére, mert bizonyos, hogy nem hagyta érintetlenül. Szintén a kutatás lehetséges kiterjesztését képezheti annak feltárása, hogy milyen problémákat és feszültségeket generálnak a bevándorlók a helyi társadalomban, vagy hogy hogyan látják a Sopronba betelepülők integrálódásuk lehetőségeit.

\section{Köszönetnyilvánítás}

A kutatás az EFOP-3.6.1-16-2016-00018 - A felsőoktatási rendszer K+F+I szerepvállalásának növelése intelligens szakosodás által Sopronban és Szombathelyen címü projekt támogatásával valósult meg.

\section{Irodalom}

Bálint L., Daróczi G. (2014): A belső vándorlások fókuszáltsága Magyarországon, 1980-2011. Statisztikai Szemle, 1., 53-70.

Clark, A. V. W., Huang, Y. (2004): Linking migration and mobility: Individual and contextual effects in housing markets in the UK. Regional Studies, 6., 617-629. http://doi.org/dn45rc

Dittrich-Wesbuer, A., Föbker, S., Osterhage, F. (2008): Demographic change and migration in city regions: Results from two German case studies. Zeitschrift für Bevölkerungswissenschaft, 3-4., 315-351. http://doi.org/cbjw5p

Dövényi Z. (2007): A belföldi vándormozgalom strukturális és területi sajátosságai Magyarországon. Demográfia, 4., 335-359.

Dövényi Z. (2009): A belső vándormozgalom Magyarországon: folyamatok és struktúrák. Statisztikai Szemle, 7., 748-762.

Flowerdew, R. (2004): Introduction: Internal migration in the contemporary world. Regional Studies, 6. , 615-616. http://doi.org/bfbqk5

Gärtner, S. (2016): New macroeconomic evidence on internal migration in Sweden, 1967-2003. Regional Studies, 1., 137-154. http://doi.org/f23qx6

Ginter G. (2008): A belső vándorlások településhálózati jellegzetességei 1990-től napjainkig. In: Szónokyné Ancsin G. (szerk.): Magyarok a Kárpát-medencében. SZTE TTK, Szeged, 245-254.

Green, E. A. (2004): Is relocation redundant? Observations on the changing nature and impacts of employment-related geographical mobility in the UK. Regional Studies, 6., 629-642. http://doi.org/cvq83m

Hamilton, F. E. I. (1995): Re-evaluating space: Locational change and adjustment in Central and Eastern Europe. Geographische Zeitschrift, 2., 67-86. 
Hilbert B. (2016): Ausztria és Magyarország migrációs kapcsolata a dualizmus idején (1870-1910). Földrajzi Közlemények, 4., 285-295.

Illés S. (1995): A területi mobilitás volumenének változásai. Statisztikai Szemle, 7., 543-556.

Illés S. (1998): A belső vándorlások alakulása és tényezői Magyarországon a XX. század utolsó évtizedeiben. KSH NKI, Budapest

Ishikawa, Y. (2011), Impact of the economic crisis on human mobility in Japan: a preliminary note. Belgeo, 3-4., 129-147.

Jankó F. (2004): Szuburbán folyamatok Sopron térségében: a Lőverek átalakulása. Földrajzi Értesito”, 3-4., 295-312.

Jankó F., Bertalan L. (2009): Egy sosem volt iparváros ipari öröksége: barnamezők Sopronban. Tér és Társadalom, 4., 1-26. http://doi.org/cwwz

Kapitány G. (1998): A munkavállalási célú területi mobilitás jellemzői. Területi Statisztika, 5., 463-475.

Kemper, F-J. (2004): Internal migration in Eastern and Western Germany: Convergence or divergence of spatial trends after unification? Regional Studies, 6., 659-678. http://doi.org/fdndmt

Kincses Á. (2012): A Kárpát-medence ezredforduló utáni migrációs hálózatának vizsgálata. KSH, Budapest

Kiss É. (2011): A válság területi konzekvenciái az iparban. Területi Statisztika, 2., 161-180.

Kiss É. (2016): A népesedési folyamatok és a népesség néhány sajátossága Sopronban a rendszerváltozás után. Soproni Szemle 4., 428-449.

Kulu, H., Billari, C.F. (2004): Multilevel analysis of internal migration in a transitional country: The case of Estonia. Regional Studies, 6., 679-698. http://doi.org/dbp2bb

Kumpulainen, M. (1994): Individual motives and processes in migrating to the countryside. Migration: A European Journal of International Migration and Ethnic Relations, 3-4., 125-155.

Kurkó I. (2011): Effects of internal migration on emphasizing territorial disparities. Studia Universitatis Babes-Bolyai Geographia, 1., 117-126.

Lukić, T., Bubalo-Źivković, M., Derčan, B., Jovanović, G. (2014): Population growth in the border villages of Srem, Serbia. Acta Geographica Slovenica, 1., 51-67. http://doi.org/cww2

Mainardi, S. (2004): Regional disparities and migration: Linear and switching model estimations for Poland. Regional Studies, 7., 767-781. http://doi.org/ddgjwf

March, H., Perarnau, J., Sauri, D. (2012): Exploring links between immigration, ageing and domestic water consumption: The case of the metropolitan area of Barcelona. Regional Studies, 2., 229-244. http://doi.org/fnqqjk

Mikačić, V. (2000): Spatial mobility of the population of Croatia - Internal migration. Hrvatski Geografski Glasnik, 1., 1-23.

Niedomysl, T. (2011): How migration motives change over migration distance: Evidence on variation across socio-economic and demographic groups. Regional Studies, 6., 843-855. http://doi.org/b98jrx

Peeters, L. (2008): Selective in-migration and income convergence and divergence across Belgian municipalities. Regional Studies, 7., 905-923. http://doi.org/b9nkzt

Sik E., Szeitl B. (2016): Migráció a mai Magyarországról. Educatio, 4., 45-58.

West, C., Gans, P., Schmitz-Veltin, A. (1994): Cities in space and city as place. Rethinking reurbanisation: Urban, semi-urban and suburban orientation and their impact on the choice of residence. Zeitschrift für Bevölkerungswissenschaft, 3-4., 381-409.

Zábrádi Zs. (2005): A magyar közép- és nagyvárosok migrációs trendjei az elmúlt negyed században. In: Perczel Gy., Szabó Sz. (szerk.): 100 éve született Mendöl Tibor. Emlékkötet. Trefort Kiadó, Budapest, 161-177. 